\title{
GOITER MULTINODUL DENGAN PELEBARAN KE RETROSTERNAL: LAPORAN KASUS
}

\section{Gede Budhi Setiawan}

Divisi Bedah Onkologi, Departemen Ilmu Bedah, Fakultas Kedokteran Universitas Udayana, Rumah Sakit Umum Pusat Sanglah, Denpasar, Bali. Korespondensi: dhiwans@ hotmail.com.

\begin{abstract}
ABSTRAK
Latar belakang: goiter multinodul retrosternal merupakan massa tiroid yang meluas sampai sternum hingga mengisi ruang inlet torakal. Dapat disebut retrosternal multinodul tiroid apabila massa tiroid lebih dari separuhnya berada di dalam inlet torakal. Pembedahan merupakan pilihan utama. Pilihan pembedahan yaitu dengan insisi collar dan sternotomi, clamshell insisi, bahkan sampai thorakotomi. Kasus: dilaporkan kasus pasien wanita 62 tahun dengan goiter multinodul hingga retrosternal. Hasil USG menunjukkan struma diffusa kiri dengan kista multipel kompleks pada tiroid kanan. CT Scan didapatkan massa tiroid multipel kiri dengan gambaran nekrosis sentral dan kalsifikasi egg shell, dan infiltrasi toraks. Dari foto toraks didapatkan massa di leher kiri yang meluas hingga rongga toraks yang tampak mendesak trakea ke kanan. Telah dilakukan total tiroidektomi, sternotomi, dan trakeostomi. Simpulan: Operasi pengangkatan goiter substernal dapat dilakukan dengan pendekatan leher di sebagian besar pasien tetapi dalam beberapa kondisi, pasien melakukan pendekatan leher dan sternotomi.
\end{abstract}

Kata kunci: goiter multinodul retrosternal, tiroidektomi, sternotomi.

\section{MULTINODULAR GOITER WITH RETROSTERNAL EXTENSION: CASE REPORT}

\section{Gede Budhi Setiawan}

Surgical Oncology Division, Department of Surgery, Faculty of Medicine Udayana University, Sanglah General Hospital, Denpasar, Bali. Correspondence: dhiwans @ hotmail.com.

\begin{abstract}
Background: retrosternal goiter refers to the thyroid mass grows along dermal sternum from the neck to the substernal portion, descending below the thoracic inlet. The current accepted definition of retrosternal goiter is thyroid gland with more than $50 \%$ of its mass located below the thoracic inlet. Surgery is the treatment choice of retrosternal goiter. Nowadays, several surgical options have been used for the surgical resection of this type of goiters, which is related to the size of the gland and the location, such as collar neck incision or/and sternotomy, clamshell incision or even thoracotomy. Case: we reported female 62-year-old with multinodular goiter with retrosternal extension. Ultrasonography showed diffuse mass of left thyroid and multiple complex cyst of right thyroid. CT Scan examination revealed multiple mass of left thyroid with central necrotic and egg shell calcification, and infiltrated thorax. Thorax x-ray showed mass derived from left neck to intra thoracic cavity and there is deviation of trachea to the right. Fine needle aspiration biopsy shows colloid nodule and follicular neoplasm. We perform total thyroidectomy, sternotomy, and tracheostomy. Conclusion: Surgical removal of substernal goiters can be performed by a cervical approach in the majority of patients but in some condition, patient performed cervical and sternotomy approach.
\end{abstract}

Keywords: retrosternal multinodular goiter, total thyroidectomy, sternotomy. 


\section{PENDAHULUAN}

Goiter retrosternal mengacu pada massa tiroid yang tumbuh sepanjang sternum dari leher ke bagian substernal, turun di bawah inlet torakal. Tiroid retrosternal mencakup kelenjar tiroid dengan lebih dari 50\% dari massa yang terletak di bawah inlet torakal. Pembedahan adalah pengobatan pilihan untuk tiroid retrosternal. Saat ini, pilihan operasi yang berbeda telah digunakan untuk reseksi jenis goiter ini, yang berkaitan dengan ukuran kelenjar dan lokasinya, seperti sayatan leher collar atau dengan sternotomi, sayatan clamshell, atau bahkan torakotomi. ${ }^{1}$

Meskipun sebagian besar goiter retrosternal adalah ekstensi dari leher, goiter intra torakal murni, mungkin terjadi. Goiter retrosternal lebih cenderung di sisi kiri dan sangat jarang meninggalkan sisi kiri kemudian turun ke sisi kanan toraks yang disebut "crossed substernal goiter". Dengan beberapa pengecualian, goiter yang besar mungkin dioperasi dengan pendekatan servikal tetapi sekitar kurang dari $2 \%$ pasien membutuhkan pendekatan servikal dan sternotomi. ${ }^{1}$ Dalam artikel ini kami melaporkan kasus langka wanita berusia 62 tahun yang memiliki goiter multinodular dengan ekstensi retrosternal yang sangat besar. Tumor diangkat melalui pembedahan dengan pendekatan servikal dan sternotomi.

\section{LAPORAN KASUS}

Seorang wanita 62 tahun datang ke pusat kanker kami dengan keluhan utama adanya massa leher yang besar sejak 20 tahun yang lalu. Pemeriksaan lokal mengungkapkan pembengkakan kelenjar tiroid yang difusa (Gambar 1).

Pemeriksaan radiologis dilakukan (Gambar 2) dan ultrasonografi menunjukkan adanya massa difusa tiroid kiri dan kista kompleks multipel tiroid kanan. Computed tomography (CT) scan leher menunjukkan adanya lesi multipel padat pada tiroid kiri berukuran 5,6 x 5,6 $\mathrm{cm}$ dengan peningkatan kontras dan nekrosis sentral. Lesi lain berukuran 6,0 x $4,6 \mathrm{~cm}$ dengan kalsifikasi egg shell dan peningkatan kontras. Nodul multipel kanan dengan peningkatan kontras, diameter 1,7 $\mathrm{cm}$. Massa memanjang ke inlet torakal dan menggeser trakea ke kanan. Tidak ada limfadenopati servikal.

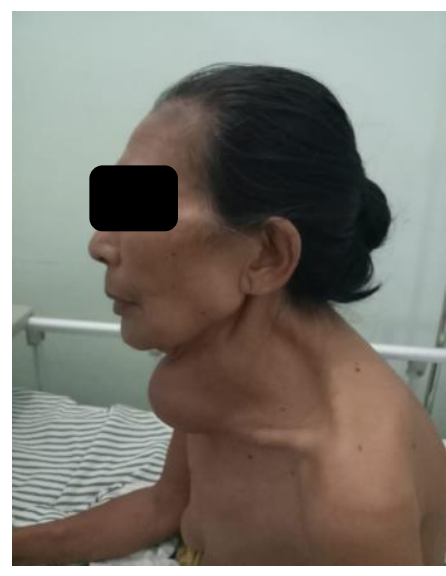

Gambar 1. Gambaran klinis

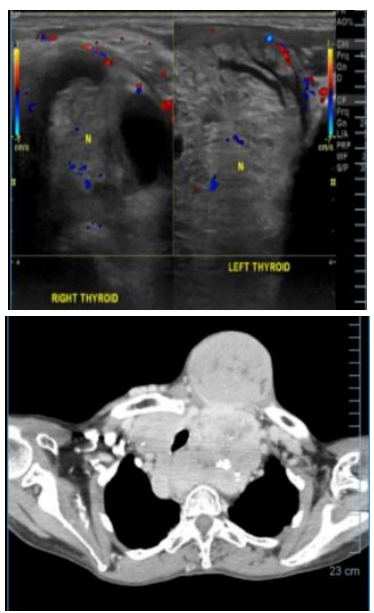

Gambar 2. Pemeriksaan ultrasonografi dan CT scan leher.

$X$-ray toraks (Gambar 3) menunjukkan massa yang berasal dari leher kiri ke intra toraks dan ada pergeseran trakea ke kanan. Hasil biopsi aspirasi jarum halus menunjukkan nodul koloid dan neoplasma folikel. Uji fungsi tiroid (FT4 dan TSH) 
dilakukan, yang mana FT4 2,00 ng/dL dan TSH $0,03 \mu \mathrm{IU} / \mathrm{mL}$.

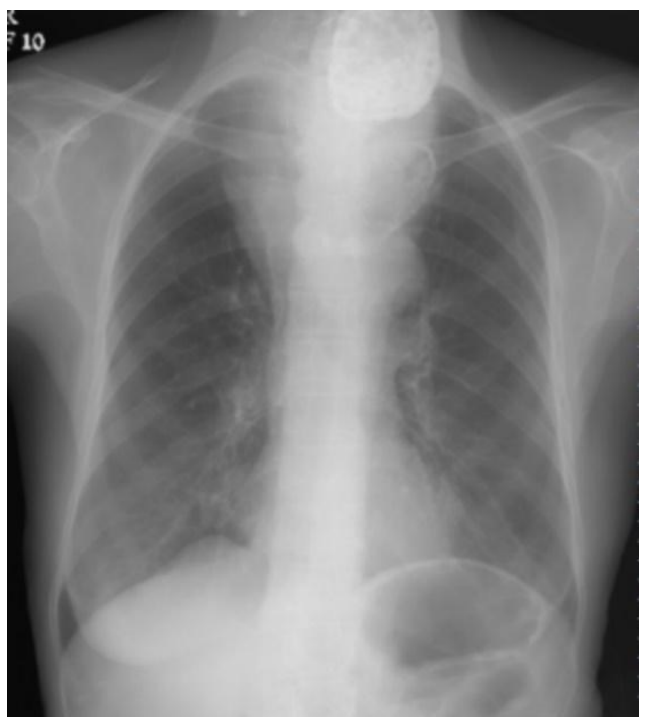

Gambar 3. $X$-ray toraks.

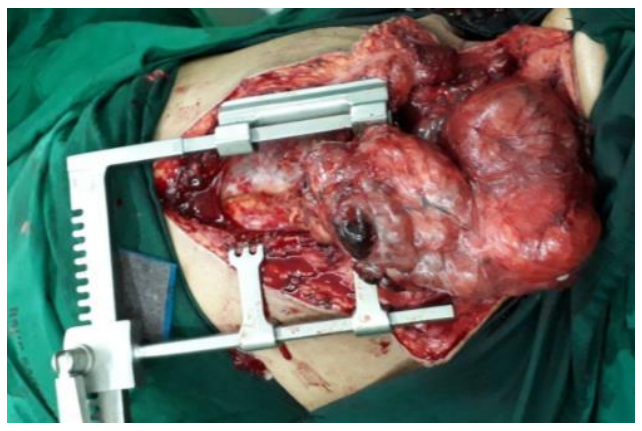

Gambar 4. Posisi kelenjar tiroid.

Pembedahan dilakukan dengan anestesi umum dan sayatan collar dilakukan $2 \mathrm{~cm}$ di atas sternum. Otot strap kemudian dipisahkan sampai tampak kelenjar tiroid. Kelenjar tiroid kiri dimobilisasi lebih dahulu kemudian diikuti dengan kelenjar tiroid kanan. Kedua saraf laringeal rekuren diidentifikasi dan diamankan (Gambar 4). Setelah tiroid kiri dibebaskan, dilanjutkan dengan tiroid kanan. Sternotomi dilakukan untuk enukleasi massa retrosternal. Kelenjar tiroid bersama dengan massa retrosternal dipotong (Gambar 5). Trakeostomi dilakukan untuk menjaga patensi saluran napas. Pada kasus ini pasien keluar rumah sakit setelah menjalani perawatan 21 hari.
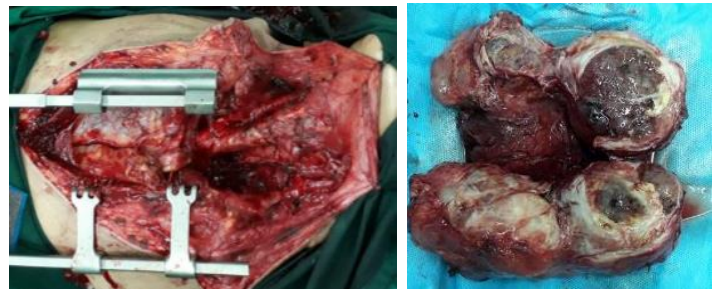

Gambar 5. Kelenjar tiroid dan massa retrosternal sudah dieksisi.

\section{DISKUSI}

Pembedahan adalah pengobatan pilihan untuk goiter retrosternal dengan atau tanpa gejala klinis. Definisi gioter retrosternal tidak seragam dan sering bervariasi di antara penulis. Menurut Katlic dan rekanrekan goiter retrosternal adalah ketika lebih dari 50\% dari massa terletak jauh ke outlet toraks. Pasien sering mengeluh pertumbuhan massa yang lambat dan pertumbuhan massa progresif biasa terjadi pada dekade kehidupan ke-5 atau ke- 6 . $^{2}$ Goiter retrosternal dapat menyebabkan gangguan pernapasan, disfagia, kompresi vaskular, dan bahkan menimbulkan kematian mendadak. $^{3-5}$

Kondisi tersebut tidak jarang dan risiko keganasan antara 3-21\%. Operasi pengangkatan goiter substernal dapat dilakukan dengan pendekatan servikal pada sebagian besar pasien. Telah dilaporkan bahwa ahli bedah yang ahli, dengan pengalaman operasi tiroid yang baik, perlu melakukan pendekatan ekstra servikal pada 2-5\% tiroidektomi untuk goiter substernal, tetapi beberapa penulis telah melaporkan kejadian sternotomi terjadi pada $29 \%$ pasien. CT scan telah menjadi standar emas investigasi radiologi pra operasi untuk penilaian massa tiroid dengan ekstensi substernal dan hubungannya dengan struktur yang berdekatan, dan juga dapat digunakan dalam menentukan pasien yang kemungkinan akan memerlukan pendekatan toraks. Beberapa orang telah 
meneliti faktor-faktor yang meningkatkan kemungkinan sternotomi. ${ }^{4}$

Flati dkk menyatakan bahwa sternotomi tidak dapat dihindari ketika gondok lebih dari $70 \%$ berada di dalam mediastinum. Beberapa penulis telah menyatakan operasi revisi sebagai indikasi yang mungkin untuk sternotomi. ${ }^{5}$ Sternotomi hanya boleh digunakan ketika goiter tidak dapat diekstraksi dari toraks dengan "manuver lembut", juga dalam kasus semua gondok yang berulang dan menyimpang. ${ }^{4}$ Di sisi lain sternotomi diperlukan ketika traksi yang berlebihan diperlukan selama operasi, ketika perluasan yang paling inferior dari nodul dapat dipalpasi, dalam kasus operasi revisi, adanya kompresi trakea akut, obstruksi vena yang parah, keganasan, dan diagnosis preoperatif yang tidak jelas. Banyak rekomendasi sternotomi untuk nodul substernal ganas, goiter mediastinum posterior dengan ekstensi kontralateral, goiter mediastinum dengan suplai darah dari mediastinum, gondok yang menyebabkan sindrom vena cava superior, kasus operasi revisi, jika eksisi massa toraks yang sulit, perdarahan yang signifikan, dan ketika diameter nodul mediastinum secara signifikan melebihi diameter inlet torakal. ${ }^{4}$

\section{SIMPULAN}

Goiter retrosternal cukup umum dan dapat diagnosis secara klinis dan radiologis yang jelas. Pembedahan merupakan pilihan utama. Operasi pengangkatan goiter substernal dapat dilakukan dengan pendekatan servikal di sebagian besar pasien tetapi dalam beberapa kondisi pasien melakukan pendekatan servikal dan sternotomi. CT scan dapat digunakan dalam menentukan pasien yang kemungkinan akan membutuhkan pendekatan toraks.

\section{DAFTAR PUSTAKA}

1. Mohammad A, Rajnish N, Shirsendu $\mathrm{R}$, et al. Huge Nodular Goitre with Retrosternal Extension-A Rare Case Report. J Otolaryngol ENT Res. 2017;7:00215.

2. Wang L-S. Surgical management of a substernal goiter. Formosan Journal of Surgery. 2012;45:41-4.

3. Sheng YR, Xi RC. Surgical approach and technique in retrosternal goiter: Case report and review of the literature. Ann Med Surg (Lond). 2016;5:90-2.

4. Coskun A, Yilridim M, Erkan N. Substernal Goiter: When is Sternotomy Required? Int Surg. 2014;99;419-25.

5. Rodrigues J, Furtado R, Anant R, et al. A rare instance of retrosternal goitre presenting with obstructive sleep apnea in a middle-aged person. Int J Surg Case Rep. 2013;4:1064-6. 